\title{
Engineering Consultants' Perceptions of Corporate Branding: A Case Study of an
}

\section{International Engineering Consultancy}

\author{
Alireza Sheikh ${ }^{1}$ \\ University of Leicester \\ School of Management \\ Ken Edwards Building \\ Leicester LE1 7RH
}

Ph: (0)116 2522461

Email: as511@1e.ac.uk

Biography: Alireza is currently completing his PhD at the School of Management, University of Leicester. His research focuses on corporate branding in the engineering consultancy sector. He holds a BSc. in Industrial Engineering and an MSc. in Industrial Marketing.

Ming Lim (Dr.)

University of Leicester

School of Management

Ken Edwards Building

Leicester LE1 7RH

Ph: (0)116 2523999

Email: $\underline{\text { m1170@1e.ac.uk }}$

\footnotetext{
${ }^{1}$ Please direct all correspondence to this author
} 
Biography: Ming is a Lecturer in Critical Marketing at the School of Management, University of Leicester. She completed her PhD in Marketing and Strategy (Information Systems) at the University of Cambridge and her research and teaching focus on global branding, social marketing, consumption, political marketing and social theory. 


\title{
Engineering Consultants' Perceptions of Corporate Branding: A Case Study of an International Engineering Consultancy
}

\begin{abstract}
The corporate branding literature on $\mathrm{B} 2 \mathrm{~B}$ markets has developed fairly rapidly over the past decade. However, empirical support on employees' perception of corporate branding is very limited, particularly with respect to employees who fall outside the marketing/branding function within their organisations. This paper explores engineering consultants' views - as an under-researched context - on the implications of corporate branding. Findings reveal engineers' views about the significance of personal brands, the implications of incorporation, the ways in which corporate branding is carried out in their organizations, and associations of technical proficiency with the corporate brand. From the findings, four hypotheses have been developed for future research.
\end{abstract}

Keywords: Corporate Branding, B2B Context, Engineering Consulting 


\section{Introduction}

Research in business-to-business (B2B) branding has developed fairly rapidly over the past two decades. While earlier studies had demonstrated the general relevance and significance of branding in B2B settings (Shaw et al., 1989; Mudambi et al., 1997; Mudambi, 2002; Lynch, 2004; Shipley and Howard, 1993), more recent research has, helpfully, focused more specifically on branding in different B2B contexts, such as the creative arts sector (Powell and Dodd, 2007), construction services (Blombäck and Axelsson, 2007), property (Roberts and Merrilees, 2007), logistic services (Davis et al., 2008) and commodity products (McQuiston, 2004).

Corporate branding, on the other hand - as a set of activities which aims to align different strategic elements so that a coherent and powerful vision "casts one glow over a panoply of products" rather than being diffused over individual product lines (Hatch and Schultz, 2001, pp. 129-130) - forms a somewhat separate stream of research from that referred to above. Within this stream, the financial benefits of a strong corporate brand (Glynn et al., 2007; Kotler and Pfoertsch, 2007; Kotler et al., 2006), its economic and emotional significance for internal stakeholders (under the rubric of brand equity) (Baumgarth and Schmidt, 2010; Persson, 2010; Burmann et al., 2009) and its significance for enhancing employability (Edwards, 2010; Moroko and Uncles, 2008; Backhaus and Tikoo, 2004) have been demonstrated. Also, a few studies in the literature of internal branding - which is again rather disconnected from the corporate branding literature - have addressed the implications of corporate branding for employees (Baumgarth and Schmidt, 2010; King and Grace, 2008; Punjaisri and Wilson, 2007; Jurg et al., 2008; Baumgarth, 2010).

While much has been said on how corporate branding should be managed to make a success, however, there is, currently, very little empirical research which investigates how the 
corporate brand and its practice(s) are perceived by employees. Data from less-researched B2B contexts and less-studied employee bases is particularly scarce. Moreover, extant corporate branding theories are (still) largely written by, and for, (pro-) marketing scholars. Given that corporate branding is supposed to engage marketing and non-marketing employees in practice, it is time that non-marketing practitioners in $\mathrm{B} 2 \mathrm{~B}$ contexts are more actively studied for their views. The findings of this paper are in line with industrial branding authors' recommendations to pursue rich, in-depth and nuanced empirical research in underresearched B2B settings (Beverland et al., 2007; Lynch and Chernatony, 2007; van Riel et al., 2005; Sheth and Sharma, 2006; Wallace and Chernatony, 2007; de Chernatony and Dall'Olmo Riley, 1998).

In this regard, engineering consultancy - as a widely neglected context with respect to corporate branding - provides a valuable source of insight into how employees outside the conventional marketing disciplines or departments perceive the implications of corporate branding to their organizations. Engineering consulting, amongst other professional services, is characterised by an autonomous employee base, weak structures of incorporation (resulting in professional partnerships), a project-based approach to work (as opposed to predefined functional departmentalization) and complex business processes (Greenwood et al., 2006). Extant research in knowledge-intensive sectors hardly addresses the corporate brand phenomenon as such and the ways in which it affects employees' attitude and behaviour (Kärreman and Rylander, 2008). Since employees' interpretation of their corporate brand reflects and determines how a consulting brand deals with its associates, a holistic understanding of B2B corporate branding along with adequate appreciation of the employee base is necessary. 
The objective of this paper is, therefore, to address these gaps by providing further empirical insight into extant corporate branding theories through an exploration of engineers' views on corporate branding.

Our research is inductive in nature, facilitating the gathering of rich insights into how employees in U.K.-based engineering consultancies perceive corporate branding efforts by top management. Hence, we did not enter the field with pre-determined frameworks or models, nor did we aim to test clearly-defined propositions. On the other hand, several frameworks on corporate branding, personal branding, corporate identity-management and the implications of the incorporation/partnership structure for corporate brand initiatives were clearly highly pertinent to our study and we anticipated that at least some of the key themes they explore would emerge in our fieldwork.

\section{Summary of Literature}

\section{Alignment between elements of the corporate brand}

Corporate branding theories are fairly well-developed in the literature (de Chernatony, 1999; Knox et al., 2000; Knox and Bickerton, 2003; Urde, 2003; Hatch and Schultz, 2001; Gray and Balmer, 1998; Balmer and Soenen, 1999; de Chernatony and Segal-Horn, 2003). Most of the theories revolve around the notion of alignment between various organizational functions, stakeholder views and corporate brand attributes. Hatch \& Schultz (2001), for instance, define corporate branding as maintaining alignment between three main constructs: strategic vision, organizational culture and stakeholder image. Strategic vision is mainly associated with top management's views and intentions, organizational culture is the context for employees' attitude and behaviour, and image is the perception of the corporate brand held by external stakeholders. According to the authors, these three strategic stars must occur "concurrently" (p. 130) rather than in a linear, sequential fashion. Companies must plan 
carefully in order to close the "vision-culture gap", the "image-culture gap" as well as the “image-vision gap” (pp. 130-132).

To Urde (2003), as another example, corporate branding is about alignment between core values of the corporate brand, added values (values appreciated by external stakeholders), and organizational values (values lived by internally through employees' attitude, behaviour, and services). This implies that values need constant rejuvenation: as external values change, internal values should equally adapt. Customers' values are, however, prioritized over other stakeholders and it is the corporate brand that should adapt with externally demanded values.

Whilst extant theories have undoubtedly provided valuable frameworks for companies seeking to build a cohesive umbrella brand which can cover different products and services, the concept of 'alignment' remains controversial and contested. Some have warned that alignment should not be misconceived as mere sameness (Hatch and Schultz, 2008; Schultz et al., 2005; Holt, 2002; Charters, 2009). Others emphasize that the alignment of relationships and interactions between companies and their stakeholders should be a key priority for firms (Antorini and Andersen, 2005; Antorini and Schultz, 2005). Yet, as a rule of thumb, most theorists agree that minimizing gaps between the different stakeholder perspectives upon the corporate brand is a desirable goal.

\section{Misalignment of multiple identities: Corporate identity and the corporate brand}

An even more fundamental question for corporate brand researchers relates to the "multiple identities" (Balmer and Greyser, 2002) which companies promote and communicate, depending on what stage they are at, who they are aiming to communicate with and their strategic goals at any point in time. Furthermore, these multiple identities may conflict with how employees see themselves and the personal values they adhere to. Using a framework they call $\mathrm{AC}^{2} \mathrm{ID} \mathrm{Test}^{\mathrm{TM}}$ (ibid., 2002), the authors define five identities - actual identity, 
communicated identity, conceived identity, ideal identity and desired identity - which they point out may themselves vary between different stakeholder groups. For example, a company's ‘communicated identity' may be perceived differently by different groups.

According to the authors, top management ought to "manage identities so that they are broadly consonant with each other" (ibid., p. 75). The five identities can suffer misalignments and unless managers are sensitive to how key stakeholders perceive these misalignments, the corporate brand can suffer considerable damage. While the framework proposed by (Balmer and Greyser, 2002) powerfully illustrates the potential impacts misaligned identities can have on both external as well as internal audiences, it does not offer, in our view, a sufficiently nuanced account of how employees outside the traditional 'marketing departments' of companies perceive top leadership's 'desired' identity (i.e. that mapped out by the CEO or the Board).

The question of how managers both perceive, and also communicate, the corporate brand is further discussed by de Chernatony and Dall'Olmo Riley (1998:1077). By testing the "atomic model" of the brand on brand experts - based on the attributes of "functional capability, symbolic features, service, distinctive name, ownership, shorthand notation, legal protection, risk reducer and strategic direction" (ibid.) - the authors discover that a much more dynamic model is needed to capture their interviewees' intuitions that a brand's mission, values, corporate culture and heritage were also important. Those elements, together with customers' perceptions, constantly swirl and spin in tandem with changing realities. Hence, de Chernatony and Dall'Olmo Riley (1998:1085) devise a “double vortex model” to capture the synergies between corporate vision/mission and consumers' behaviour and perceptions. Their research raises intriguing questions about how other organizational perspectives interact with brand vision, mission and values. In other words, more research is 
needed into how such a model can be made useful when other perspectives are specified. For example, how might employees' perceptions interact with consumers' perceptions when a brand's values and an organization's corporate culture come under pressure from internal or external sources?

The role of middle management and employees in branding campaigns is a key concern of other researchers (Järventie-Thesleff et al., 2011; Ind, 2004). The interanimations between corporate and personal brands, for instance, particularly in knowledge-intensive contexts, have been discussed (Alvesson, 2004; Shepherd, 2005; Hearn, 2008). The issue of alignment between the corporate vision and the employees' perception (as well as their perceptions of how customers might react to breaches of the brand covenant) is, again, highly relevant here. As Wallace and Chernatony (2007:91) note, "Employees are the public face of the organisation, and their performance affects customers' interpretation of the brand". Employees can, and do, sabotage the brand out of frustration, fear and/or work-related stress (Wallace and de De Chernatony 2007; Ind, 2004).

\section{Partnership and Incorporation}

Finally, the corporate brand undergoes specific changes in professional services contexts. A rich body of literature has explored the engineering consulting sector, particularly from the Organization Studies (OS) perspective (Alvesson, 2000; Alvesson and Kärreman, 2004; Kunda, 2006; Carmeli and Waldman, 2009; Jennings et al., 2009; Whittington et al., 2009; Starbuck, 1992). However, special attention to this context with respect to corporate branding is scarce. Nuanced empirical evidence, instead of a few extant anecdotal accounts, is required to illuminate the implications of corporate branding in the context of engineering consulting.

In this regard, Greenwood and Empson (2003) and Greenwood et al. (2006) have discussed extensively the intrinsic tensions between the two organizing forms of Incorporation and 
Professional Partnership within knowledge-intensive contexts. While the former is associated with integrative efforts, standardization of processes, and total communication, the latter is called upon to maintain individual (and collective) autonomy, flexibility, and ownership. Hence, corporate branding which, by definition, well resonates with the notion of incorporation, is no exception in terms of its tensions with employees' efforts in pursuit of sustaining professional partnership. This paper sheds further light on such tensions.

Based on the summary of literature, this paper aims to investigate how employees perceive corporate branding. Since it is clear that further empirical research is needed, the perceptions of engineering consultants, as an under-researched internal stakeholder base, are sought for their views on how they view the corporate brand and their relationship to it and the various corporate branding activities undertaken by their organisations. The research gaps referred to above which our paper addresses are summarized in Table 1.

Table 1: Gaps identified in the literature with respect to the contributions of the paper

\begin{tabular}{|l|l|}
\hline Authors & Research Gaps \\
\hline $\begin{array}{l}\text { (Hatch and Schultz, 2001; de } \\
\text { Ind, 2004; Hatch and Schultz, } \\
\text { 2003; Balmer and Greyser, 2003) }\end{array}$ & $\begin{array}{l}\text { Corporate branding conduct - i.e. the way corporate } \\
\text { branding should be carried out and managed in practice } \\
\text { somewhat vague, particularly in the engineering } \\
\text { consulting context }\end{array}$ \\
\hline $\begin{array}{l}\text { (Ind, 2004; Schultz and Hatch, } \\
\text { 2003) }\end{array}$ & $\begin{array}{l}\text { The role and significance of the corporate brand as } \\
\text { compared to technical knowledge have been } \\
\text { understated }\end{array}$ \\
\hline $\begin{array}{l}\text { (Alvesson, 2004; Alvesson and } \\
\text { Kärreman, 2004) }\end{array}$ & $\begin{array}{l}\text { The role of personal brands in relation to the corporate } \\
\text { brand have been under-imagined and under-researched }\end{array}$ \\
\hline $\begin{array}{l}\text { (Greenwood } \text { et al., 2006; } \\
\text { Greenwood and Empson, 2003) }\end{array}$ & $\begin{array}{l}\text { The implications of incorporation for corporate } \\
\text { branding have been understated }\end{array}$ \\
\hline
\end{tabular}




\section{Research Aims and Methodology}

Based on the existing deficiencies in the literature, we wanted to explore how engineers in consultancies perceive corporate branding within their organisations and how they make sense of the different elements of the corporate brand. The central research question, therefore, is how engineers perceive corporate branding and its implications.

To avoid imposing any presumptions on employees and to deploy rich and nuanced data, an inductive qualitative approach was adopted for this enquiry. A case study design was chosen in order to elicit a more nuanced understanding of how corporate branding activities are perceived by engineering consultants based on real-life accounts of their experiences. Case study design is suitable when theorization of the phenomenon under study and the key constructs or themes are yet to be identified (Stake, 2005; Gummesson, 2000; Gummesson, 2005; Yin, 2003).

The case study was carried out within the UK arm of a multi-national engineering consulting firm. A total of 14 semi-structured and in-depth interviews, along with opportunistic observation, were the main means of collecting insights in three regional offices in the UK. All interviews were carried out one-to-one and face-to-face; these lasted between 30 to 80 minutes. Informants were selected from across grades and specifications; they were mainly males since the engineering profession in the U.K. still tends to be dominated by men (Tonso, 2006). Informants are referred to by codes in the remainder of the paper; a stratified sample of five graduate (WG1-5), five senior (WS1-5) and four director (WD1-4) engineers was obtained with comparatively equal distribution of informants at each level. Over the course of three months, key senior managers in London as well as the three participating regional offices were interviewed. This commitment from the senior management was achieved on the basis that the findings were likely to be of managerial and strategic significance to the firm's 
corporate branding activities. Financial support during the research was granted by university of Leicester, School of Management.

Access was a particular challenge because, as the directors emphasized repeatedly to us, engineers' time is rather highly-priced. To encourage reflection and enhance authenticity, managers were referred to corporate brand artefacts and initiatives during interview sessions. They were also asked to share suggestions and stories of success or failure due either to 'good' or 'poor' practices of corporate branding and to articulate their reasons for any cynicism they might feel with regard to the notion or practice of corporate branding.

Interviews were transcribed and codified thoroughly with the aid of qualitative data analysis software Nvivo 7.0.; One of the limitations in using qualitative data analysis software, as Tesch (1990) notes, is the risk of imposing rigid codes on interview accounts and suppressing multiplicity of interpretation. Hence, multiple codes were assigned to interview texts. Also, codes were further interpreted by both authors. During the coding process, excerpts from the interviews were used as code titles as much as possible to let the data speak for itself instead of imposing structures influenced by pre-understanding from the theory (Tesch, 1990). An example of the coding procedure is given in Figure 3. Using the software facilitated efficient management of rich source of data and helped better integrating and presenting the multiplicity of themes emerged from the data. It also made subsequent interpretations easier through its advanced search, reporting and comparison features.

In conducting our analyses of the data, we were guided by what Alvesson (2011) calls 'reflexive pragmatism'. Reflexive pragmatism is often deployed in marketing and industrial contexts where in-depth information is sought and provides a key for the critical assessment of interviews. It helps the researcher not only to grasp the contextual meanings of the talks and the social setting within which a conversation takes place, but also to cautiously go 
beyond the actual setting to identify more transferrable insights and to assess authenticity and trustworthiness in respondents' statements without an exaggerated concern for 'truth' or rigour.

Figure1: An extract of coding procedures using NVivo

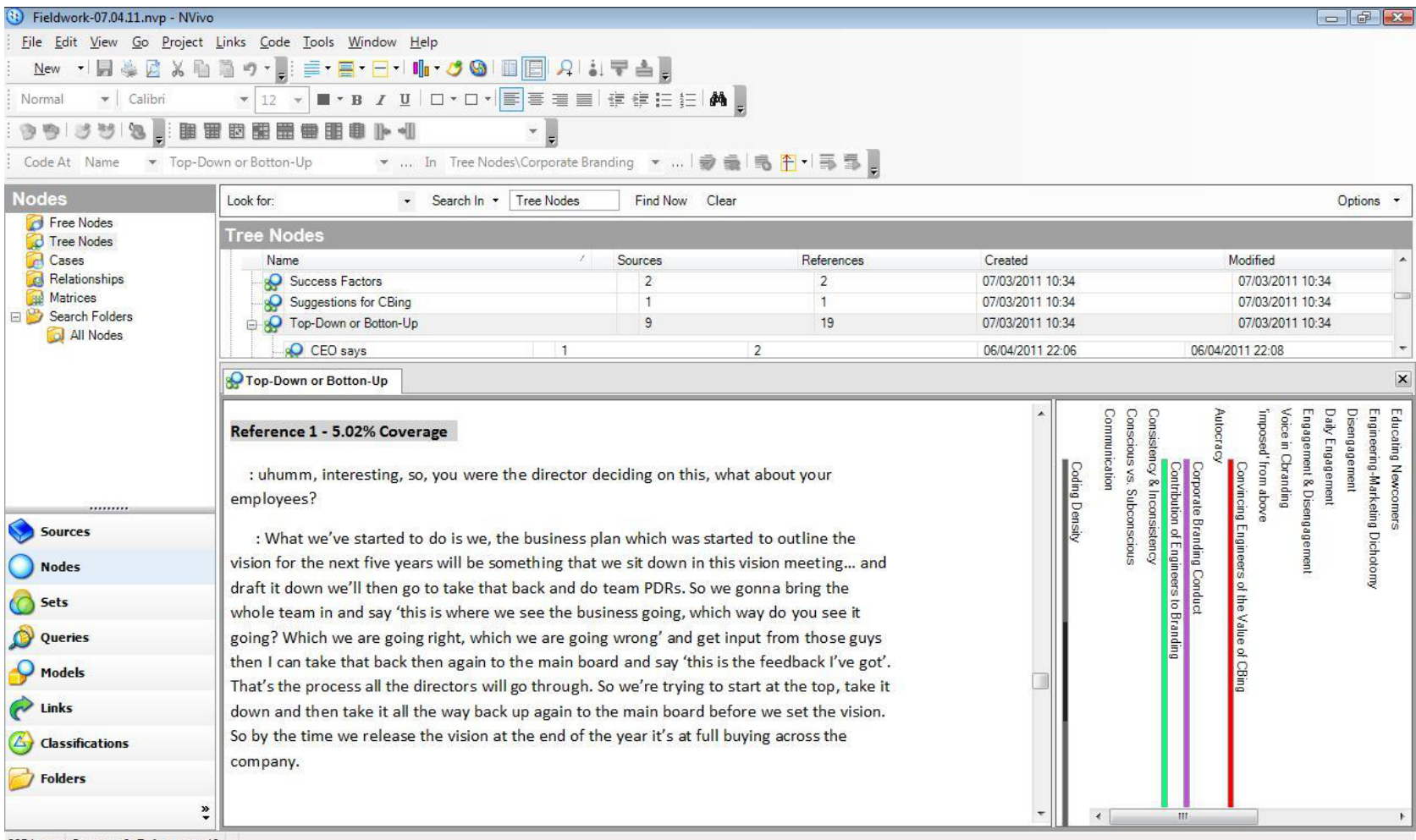

\section{WRJ Engineering Consultants ${ }^{2}$ : Case Background}

The site of investigation was three regional offices of WRJ consultants in the UK. A few years ago, the WRJ group, an already well-established Nordic engineering consultant of a few thousand employees, acquired SMB consultants, another well-established UK-based international consulting of a few hundred employees. While WRJ was mainly active in the infrastructure, energy and construction, SMB was known for its excellence in building and design. After the acquisition SMB was rebranded as WRJ-SMB for two years and then the SMB sub-brand was eliminated. Currently, the merged entity is known simply as WRJ (UK).

\footnotetext{
${ }^{2}$ All names, including company and interviewee names, are anonymised for ethical reasons.
} 
This acquisition has had some mutual benefits, as well as difficulties for both consultancies in terms of corporate image and branding. The WRJ Group, despite its large size, had by and large remained a Nordic player prior to the acquisition. Following the acquisition, it managed to break through its Nordic image and to enhance its international presence, mostly by leveraging on the established international presence of SMB. Similarly, SMB has enjoyed much larger-scale projects involving more diverse engineering expertise as a result of its acquisition by WRJ.

\section{Findings}

Engineering consulting is significantly distinctive from other business sectors in terms of it management structure (Filiatrault and Lapierre, 1997). This is partly due to the nature of engineering consulting projects: they tend to be unique in every instance (thus requiring highly individualized, customized solutions and expertise), defined through very close collaboration with the client(s) and other partners, demand high levels of technical knowledge and creativity, demand on-site presence by the consultancy or consultancies commissioned for the project and closely supervised for strict adherence to established codes of safety and practicality (Alvesson, 2004; Downey and Lucena, 2004). All these yield significant implications for the corporate branding of engineering consulting firms.

\section{Corporate versus Personal Branding}

It has already been noted that, in the engineering consultancy setting - as a highly specialized context where niche expertise is called for - employees build up significant relationships with clients and develop brands of their own. Clients are careful, even choosy, in their assessments of employees who are involved in a consultancy project due to the scale and scope of work involved. It is very common to include engineers' names and their resumés on a formal 
written proposal to clients. These personal brands can then become at par with the corporate brand (WD4, WD3).

It was highlighted by engineers interviewed that the significance of personal brands increases at more senior levels - i.e. director level or above (WD4, WS5). Therefore, a director's brand and his team play a key role in the buying behaviour of clients. The significance of personal brands also depends on the projects' size, as the role of employee brands can be offset the bigger in size the project is (WD4, WS5).

Another determining factor was reported to be the clients' personal preferences and their values. Some clients might, due to cultural characteristics, value personal relationships more than the corporate brand behind the employees' personal brands (WS1, WD2, and WD3). It was noted by most of the directors and senior engineers that the British market is characterized by ascribing particular attention to personal (still technically-oriented) relationships above corporate brands particularly in small to medium scale projects. We thus arrived at the first of our propositions:

P1. The personal brand(s) of employees in professional B2B settings can threaten to override the corporate brand, leading to confusion in external stakeholders' minds.

\section{Incorporation}

It was noted that companies "tend to become more of the organization, more of a delivery body rather than something that's changing and thinks a lot" (WS5) in their transition towards incorporation from the traditional partnership style. WS1 and WD1 also associated incorporation with 'dehumanization of the company'.

WG4 and WD1 also criticised corporate branding initiatives, those that excessively carry rules of incorporation, of exerting destructive limitations to some everyday business 
processes. Corporate branding initiatives, as a 'vehicle' for further incorporation, were equally criticised for dictating specific guidelines internally for engineers to abide by when approaching clients and bidding for projects that are not always 'helpful'. Part of the issue, was noted to be that regional employees will have to deal with much bigger sums of information, not always necessarily relevant, about the corporate information "which can at times be stressful" (WD1). More importantly, some corporate branding initiatives had often carried unnecessary, irrelevant and destructive impressions of being 'big enough not to care enough' or 'big enough not to be flexible enough' (WD1, WG4). A regional director, in reflection towards the corporate brand protocols, further explained the intricacies involved in this regard, referring to a standardized presentational package initiated by WRJ group communication centre to be used by regional offices when approaching prospective clients:

"I think... the worry is... that in a big chunk of the presentation, your personality is sort of taken out of it because I think ... some of the slides are quite definite. You don't want to joke about them or undermine them in any way, but it's quite difficult to get your personality across and I think a lot of what we do is about providing a personal service and is about how people respond to you because quite often ... they just happen to like the person who came to the interview and think, "I would trust that person to do my building". (WD1)

This also refers to the role of personal brands, as discussed earlier, whereby incorporation dilutes the influential role of personal brands. It was also outlined that associations of incorporation, such as connotations of size, can do more harm than favour when it comes to a local or regional level collaboration with prospective clients:

“...so, you have sort of this big, big thing sort of floating around like a big airship or something just hovering there and you have to refer to it ... all the time ... It's 
completely benign ... and if anything it's probably good in a lot of ways because it does give people confidence at their strength and certainly from like a financial point of view and we've got plenty of access to lots of skills. Yet, you do feel a bit like a hammer trying to crack a nut.” (WD1)

The corporate brand was therefore criticised since, most often than not, the local and regional contact points - or 'partners' in the professional partnership term - do not necessarily need to refer to the largesse or luxury associated with a monolithic corporate brand image. Instead, they need to be empowered sufficiently to be able to keep their local contacts lively and tailor their marketing and branding activities locally, at least to an appropriate degree. In this regard, some (WG4, WS1, WD1, and WS5) noted that the extant cooperate branding protocols mostly lack a local twist which clients value very much. Connotations of 'bigness' were also reported to frighten the clients, at times, thinking "well you're too big; you won't be interested in our job" (WG4). This is especially significant given the service nature of the business as well as the British engineering relationships that demand high levels of personal care, transparency and local presence (WD3). Based on these findings, our second proposition is:

P2. Incorporative activities that bear connotations of 'bigness', 'dehumanization' or 'steadiness' can undermine the corporate brand in the mind of employees as well as external stakeholders.

\section{Corporate Branding Conduct}

It became evident in the investigations that one of the most significant burdens in engaging employees with the corporate brand is, simply put, that corporate branding 'campaigns' were not compelling enough. In a few interviews it was noted that some engineers, as representatives, had been consulted about the initiatives (WD3, WG1); yet, they were 
strongly on the belief that the engineers' comments had hardly been affected the corporate branding approach in place (WS5, WS1).

Hence, corporate branding initiatives had remained a "benign" set of activities at best (WD1), something no one would even bother criticising (WS5). Some believed that corporate branding campaigns were excessively standardized and lacked humanistic and social ambience (WS1, WD1). Others noted that corporate branding initiatives fail to appreciate the substantive cultural, occupational, and geographical differences across the firm and that the initiatives had been designed in pursuit of 'integration' at any cost without devoting enough thought to nuanced differences (WS5, WG4).

It was also noted by four senior engineers that at times the corporate branding initiatives had been in clash with the extant business procedures, breached by several inconsistent corporate behaviours, or that turf battles had undermined corporate branding messages. CS5 highlighted this by referring to an ethical reservation about the places wherein the company carries out projects without exerting due sensitiveness to labour conditions in those countries:

“... It's like politicians saying back to basics and then realizing they have an affair...you got to be very careful... about standing up and giving all these values ... I don't have a problem with it, because personally I like the idea of having those values, but what those values means is saying 'No'. If you gonna have things like that, you got to be able to say 'we are not working there, or if we are working there, it's under these conditions'...Now, good, I agree with all that, yeah, but I also know that we work in Libya. Ok?"

In addition, where the content of corporate branding initiatives has been fabricated, where it is being 'aired' from and the fact that there has been almost no voice in devising it in the first place for engineers - all contributed to the lack of motivation in engaging with the initiatives. 
Besides, the five graduate engineers mentioned that having experienced the same conventions in their previous tenures make them consider all this "as a given". In another case, it was noted that it is difficult for engineers to see how branding affects the way they proceed (WG2, WS1, and WG4):

"It's on the wall for the clients. It is a marketing tool rather than it being inherent in every employee" (WS1).

Nonetheless, there were some interesting propositions made by engineers in order to make corporate branding more efficient, engaging and influential. A regional director asserted that he had started to develop and apply his own local version of corporate branding in terms of defining vision and identity in light of the overall guidelines defined by the corporation. Having adopted this approach and regarding the group corporate brand initiatives he noted:

"I can't really influence them, but I can then influence how that's applied within the UK, but I can't change group direction on that". (WD3)

The general initiatives were reported to be usually broad (and vague) enough to allow such local adaptation. With respect to the contents of initiatives, an engineer noted that he would be far keener to see "a bit more about what the company actually is" (WG4), what other offices are doing, what are the facts and figures, who are the people, what project they are doing, and what are the capabilities particularly at the local level, instead of mere 'management speak'.

At the same time, employees were not wholly indifferent to, or negative towards, the corporate brand, at least not in a straightforward way. Some senior managers as well as graduate engineers indicated that they identified with their job or the kind of projects they were involved in instead of the corporate brand. Some serious reactions had also taken place 
in response to unfavourable, 'meaningless' or authoritarian initiatives. For instance, the British communication team was actually forced to leave the group following the acquisition, due to a mismatch between the corporate branding strategies of the two firms.

Interestingly, some graduate engineers recalled very clearly the value word "excellence", although it was not among the five stated value words in the official 'corporate philosophy' statement. "Excellence" appeared to resonate well with engineers not only because everyone could easily recall the person - the Managing director (MD) - who had underscored it constantly during monthly meetings, but also because the implications of 'excellence' in the engineering processes had been clearly articulated along with real-world examples by the MD (WG4, WS2). It could be inferred that corporate branding was adopted as the 'grammar' for power discourse and that power element had directly influenced the efficiency and acceptance of initiatives.

It is also worth noting that almost all respondents failed to recall the five value words postulated in the 'corporate philosophy'. At best, they could only recall two out of the five words, despite having received extensive 'brand training' provided by the company. As one senior engineer 'confessed':

“I guess I didn't even know the brand... \{Laughing\}, the five elements that we're supposed to be selling... yeah that's true. I live my own definition of the brand. I guess I have defined the brand in my own way and that's what I feel I'm selling which, yeah, is a gap...” (WS1)

Despite gaps between how the corporate brand was communicated and how it was interpreted, the corporate brand studied was reported by engineers to be still 'meaningful' and not meaningless - in terms of image and personality. The problem was in their being able to present a holistically meaningful brand to customers. To the managers, the WRJ corporate 
brand was associated with particular types of engineering projects that were in clear contrast with those espoused by SMB in the past. Whereas SMB was recalled by graduate and senior engineers as 'creative', 'glitzy', 'challenging', 'self-generating', 'questioning', 'varied' and 'exciting', WRJ was referred to as being 'standard', 'steady', 'less exciting', 'safe', 'able', 'competent', 'grown-up', 'reliable', 'big' and 'generic'. Our third and fourth research propositions, are, therefore:

P3. Corporate branding initiatives that are carried out extensively from the top down risk alienating employees and their specialist talents and expertise, thus hurting the corporate brand.

P4. Corporate branding initiatives which fail to engage employees fully run the risk of losing brand consistency and control.

\section{The Corporate Brand versus Technical Knowledge}

A common theme throughout the case study was that the corporate brand 'at the end of the day' is less significant to the company than technical expertise. This view was presented by one director, who, in response to a question about a corporate brand statement, noted:

“...because we deal with very sort of tangible things and steel and concrete and big things and they're sort of quite serious safety issues going on, on site, you know, we're not going to get upset by a few words. You know, it's sort of not that important at the end of the day and I think there is a bit of humour there, as well, possibly." (WD1)

However, the corporate brand was not entirely insignificant either, as outlined in all interviews. On average, in response to the question of "how much of your success is indebted 
to the corporate brand and how much to technical expertise, if you want to provide a percentage?", a 40-60 split was offered in favour of technical excellence.

Similarly, engineers also appeared better prepared to engage with the technical attributes of the corporate brand (e.g. its reputation for technical excellence or the kind of projects the company had been involved in) than with the presentational aspects (e.g. logo, colour and other presentational codes). Therefore, we propose that:

P5. Because engineering consultancies rely on technical excellence, engineers show greater reliance on the technical, rather than the presentational, aspects of the corporate brand.

\section{Discussion}

It is evident from our findings that there is a certain degree of suppressed rivalry in place between the two brand types - the corporate brand and the personal brand(s). This manifested in identity struggles on the engineers' part in pursuit of maintaining individuality as well as in the discomfort expressed by engineers in coping with business process reforms aimed at standardizing reporting and knowledge management systems. In such a scenario, the personal brand of the consultant would sometimes come into conflict, or be misaligned with, the corporate brand. Over time, this misalignment can have knock-on effects on the corporate brand, further intensifying gaps between the corporate vision and organizational culture and, thereby, affecting external stakeholders' perceptions of the corporate brand (Hatch and Schultz, 2001).

The force of personal brands can, of course, be aligned with the corporate brand and create synergy as well (Greenwood et al., 2006). On the flip side, however, it can create hidden or open clashes. This resonates with the increased likelihood of a whole division's departure when senior members tend to depart (Alvesson and Kärreman, 2004). In the case studied, the 
firm's and projects' size appeared to mitigate this force and suppress (at least temporarily) more open struggles at the employee levels that can threaten the corporate brand.

Morale can also be affected when senior managers feel that the corporate brand does not accommodate their personal brand value ("your personality is sort of taken out of it"). In this case, the engineers felt they had to define the brand their own way. As a result, many of them felt that their 'personal brands' were either on par with, or surpassed, the corporate brand. A key implication of this finding is that the personal brand(s) of employees threaten to override the corporate brand, leading to confusion in external stakeholders' minds (Hatch and Schultz, 2001; Balmer and Greyser, 2002).

We also found that misalignments between corporate and personal brands have ethical implications. This finding throws into relief the difficulties professional services firms can face in selecting which projects to take on. It has been noted that managing multiple identities is a major challenge for companies (Balmer and Greyser, 2002), and our findings confirm this insight. At the same time, these accounts show that employees can often be the first to feel the discomfort of ethical misalignments between ideal identity (the corporate vision) and conceived identity (the corporate brand), even before other key stakeholders (such as customers) are made aware of them ("good, I agree with all that, but I also know we work in Libya. Ok?”).

The way corporate branding campaigns are carried out is one of the main elements that can link corporate branding and internal branding (Ind, 2004). Engaging corporate brand conduct can also encourage authentic 'alignment' between employees and the corporate brand leading to 'living-the-brand' on the employees' part (Ind, 2004). However, more often than not, more attention is being given to form rather than content (Olins, 2003). Our understanding is that 
adopting a conventional, uneducated, or contextually-inappropriate approach to corporate branding can become in itself the root cause of disengagement and fragmentation.

Adopting conventional, old-fashioned and uninteresting corporate branding initiatives had at many times discouraged engineers from active participation. This appeared to be partly because these initiatives were designed by non-engineers - i.e. by external branding consultants or internal communication executives or a combination thereof - and in an excessively top-down manner. It could be inferred that, this was due to a problematic presupposition (or lack of confidence) that engineers are marketing- and branding-illiterates and therefore it is more efficient (or easier) to take a top-down approach. In devising initiatives, 'the top' is usually senior managers (supplanted by external consultants) who are rather cut off from the lower tiers (Ind, 2004; Burmann et al., 2008; Burmann and Zeplin, 2005).

Engineers were thus, for the most part, uncommitted to the corporate brand vision (Wallace and Chernatony, 2007). So, while one director admitted that he would not actively sabotage corporate brand communications ("you don't want to joke about them or undermine them in any way"), he still felt the size of an incorporated entity militated against the specific expertise individual consultants could offer clients. A corollary of this finding is that engineers felt disengaged with branding initiatives not necessarily because they did not believe in them but rather because they (the initiatives) lacked local relevance and resonance. This finding further illuminates existing brand models which demonstrate the importance of capturing brand mission, heritage and stakeholder value (de Chernatony and Dall'Olmo Riley, 1998). Where the corporate brand did resonate with engineers, it was because they were being reminded of words like 'excellence' on a regular basis in formal meetings and by top management (MD) rather than through planned branding campaigns. It appears that work- 
focused meetings might be a more effective way of communicating the corporate brand values rather than trying to get professionals trained in what the corporate brand should look or sound like or what one graduate engineer called 'management-speak'.

The tension between the two opposing organizing structures of Professional Partnership and Incorporation with respect to corporate branding also emerged in the findings. Intrinsic to the way consulting firms classically operate is the autonomous employee base via a loose and organic structure binding knowledge arms or conglomerates together known as professional partners (Greenwood and Empson, 2003). This is mainly due to the knowledge-based nature of business processes. An adequate level of autonomy is, therefore, necessary for the knowledge-arms (being individual knowledge workers or small collectives as business units within and across the firms in a network) to best put their creative and professional ideas in place.

Such an autonomous orientation, however, clashes with the tendencies towards incorporation. As firms get bigger - and given the companies' intentions to manage knowledge and to standardize ordinary processes (such as reporting or finance and the technical processes that are common among various projects) in order to achieve managerial efficiencies incorporation is typically an almost inevitable option (Greenwood and Empson, 2003).

Incorporation is also associated with increased bureaucratic characteristics and beard connotations of slowness, steadiness and regularity while partnership was associated with autonomy, creativity and agility. Elements from the two were, however, in place and in tandem in a complementary manner. 


\section{Theoretical Contributions}

This paper brings substantive theoretical contributions to the table. First, it reveals new aspects to, and implications of, corporate branding as perceived by middle and senior managers in an engineering consulting setting. Based on our findings, five research propositions have been generated which correspond to the interactions between personal and corporate brands, the brand implications of incorporation, the ethics of personal versus corporate branding conduct and the importance of technical proficiency to the corporate brand. All these provide rich directions for further investigation in other knowledgeintensive contexts.

In terms of the relationship between the personal and the corporate brand, our paper confirms that the personal brand of the consultant can override that of the corporate brand, leading to a series of unintended consequences for the firm or parent company. These consequences include, but are not limited to, the risks associated with misalignments between corporate brand values and personal brand values (Hatch and Schultz, 2008; Schultz et al., 2005; Holt, 2002; Charters, 2009).

Furthermore, our research contributes to extant research in knowledge-intensive sectors on the corporate brand phenomenon and the ways in which employees react to it (Kärreman and Rylander, 2008) by showing that the tensions between the personal brand of knowledge professionals and the corporate brand of the firm increases with increased seniority of employees. We have also shown that the size of the corporation matters greatly: the larger the parent group of companies, the greater the danger that local and/or regional contact points are lost. Our findings in this area lend credence and specificity to the argument by Wallace and Chernatony (2007) that employees represent the corporate brand but can also sabotage it. 
Interestingly, as we have discovered, employees may not set out deliberately to sabotage the corporate brand; they may simply fall 'out of sync' with it.

As shown by this study, one of the reasons for the disenchantment with, or disengagement from the corporate brand lies in how the partnership/incorporation transition is managed (Greenwood et al., 2006; Greenwood and Empson, 2003). Incorporation can threaten employees' sense of belonging to a cohesive and unique company and undermine their sense of the corporate brand, however that is defined. It can also threaten regional or local contacts and the sense of intimacy which clients seek. This breach between employees' identity and that of the corporate brand is intensified in service settings where transparency is highly valued. As our informants emphasized repeatedly, being seen to adhere to espoused values in practice is fundamentally important in professional service settings.

Thus, ethical reservations on the part of employees play a significant role in how they interpret and respond to organizational values. As we have seen, informal observations of the company's inconsistent behaviours with respect to official standards are enough to distance employees in knowledge-intensive sectors from the corporate brand. When this happens, employees in such contexts may choose to focus on their 'own' projects or on developing their own version of branding rather than go with the corporate narrative. Urde (2003) argues that corporate branding is about aligning corporate values with the lived, internal values of employees. Our findings contribute to this and similar insights by showing that efforts at alignment need to take into account the ethical dimension of organizational value-building rather than just attempt to refresh the corporate brand for its own sake.

Relatedly, our study sheds further empirical light on extant corporate branding theories by revealing manifestations of misalignment either with respect to identities or values among internal stakeholders - i.e. employees and top management - that can undermine the 
corporate brand. That is, not only can there be cognitive dissonance between employees' professional identities and those of the corporation, there can also be tensions between different levels of the corporation. When this happens, the cynical reflections of engineers can, and are, constructively deployed by them to illuminate the shortcomings of corporate branding in practice: this is described by them in terms of failures in (controlled) brand communication, initiatives, and conduct. Thus, our study also reveals nuanced expressions of culture-vision, actual-desired, conceived-communicated, and core-organizational value gaps, thus contributing both to the model proposed by Hatch and Schultz (2001) and that presented by Balmer and Greyser (2002).

Last, but not least, we have shown that the corporate brand construct itself in B2B contexts is somewhat more nuanced than the literature might lead us to expect. What our findings show is that professional services firms rely heavily on technical aspects of excellence, more so than on brand awareness and relevance among stakeholder groups. For this reason, the engineers in our study identified more readily with the specialist competencies they have been trained to deliver to clients rather than with brand personality and promise (Kotler et al., 2006; Ohnemus, 2009).

Table 2 more explicitly summarizes the theoretical contributions of this paper.

Table 2: Theoretical contributions of the paper

\begin{tabular}{|l|l|}
\hline Article & Contribution \\
\hline $\begin{array}{l}\text { (Hatch and Schultz, 2001; Balmer and } \\
\text { Greyser, 2002) }\end{array}$ & $\begin{array}{l}\text { Demonstrates manifestations of } \\
\text { misalignment between culture-vision } \\
\text { perspectives, as well as actual-desired, and } \\
\text { conceived-communicated identity types }\end{array}$ \\
\hline $\begin{array}{l}\text { (Kärreman and Rylander, 2008; Urde, 2003; } \\
\text { Ind, 2004) }\end{array}$ & $\begin{array}{l}\text { Demonstrates manifestations of } \\
\text { misalignment between core (corporate brand) } \\
\text { and organizational (actually 'lived') values }\end{array}$ \\
\hline
\end{tabular}




\begin{tabular}{|l|l|}
\hline $\begin{array}{l}\text { (Alvesson, 2004; Shepherd, 2005; Alvesson } \\
\text { and Kärreman, 2004) }\end{array}$ & $\begin{array}{l}\text { Provides nuanced account of the tensions } \\
\text { between personal brands and the corporate } \\
\text { brand }\end{array}$ \\
\hline $\begin{array}{l}\text { (Greenwood et al., 2006; Greenwood and } \\
\text { Empson, 2003) }\end{array}$ & $\begin{array}{l}\text { Provides nuanced account of tensions } \\
\text { between incorporation and professional } \\
\text { partnership from the perspective of corporate } \\
\text { branding. }\end{array}$ \\
\hline (Kotler et al., 2006; Ohnemus, 2009) & $\begin{array}{l}\text { Levels the association of corporate brand and } \\
\text { technical proficiency in engineering-intensive } \\
\text { contexts }\end{array}$ \\
\hline
\end{tabular}

\section{Managerial implications}

This research has significant managerial implications from various perspectives. It has given rise to four central elements $\mathrm{B} 2 \mathrm{~B}$ companies need to consider when engaging in corporate branding - namely personal brands, incorporative activities, corporate branding conduct and technical expertise. It helps managers understand the constellation and implications of mentioned elements towards creating a clear corporate brand that can serve internal as well as external stakeholders. Managers should be alert to the significant role of personal brands and attempt to utilize them in order to create synergy. Furthermore, corporate branding activities that are in line with incorporative attempts should be devised, communicated and put in place with caution so that individuality, local adaptation, and autonomy of employees are not diluted. The initiatives themselves, such as value words, mission statements or training materials should also be in engineers' 'language'. In other words, instead of educating engineers on the branding materials developed by marketers or corporate brand consultants, it is better to engage them from the very beginning in the building of corporate branding initiatives - i.e. engineers doing the corporate branding from $\mathrm{A}$ to $\mathrm{Z}$. 
Such efforts and, and perhaps should, be facilitated by corporate branding consultants. For example, instead of communicating the value word "sustainable", a picture of an example of a sustainable building project with a brief introduction next to it that explains the advantages of a sustainable building project can work more effectively for aligning personal and corporate brand values than text consisting of three or five value words. Brand values, in other words, need to come alive for engineers in a way which acknowledges their technical expertise as well as their personal expression of that expertise. Further, corporate brands need to be flexible enough to accommodate highly localized contexts and individual preferences. In fact, many of our interviewees were already acting upon their own initiative, while trying hard to buy into the corporate brand itself ("I have defined the brand in my own way...yeah (that is) a gap...").

Moreover, technical expertise and corporate branding activities should not be considered as two opposing or even separate constructs. The two are complementary in the way that the former feeds the latter. Prioritising one over another is therefore problematic since a strong engineering consulting corporate brand is no different than delivering long-term and sustainable technical excellence.

\section{Conclusions}

When we first embarked upon this piece of research and spoke to colleagues about it, we were confronted with views along the lines of: 'engineers don't care about branding and why should they?' and 'don't engineers think branding is for the marketing department to handle?'. We were driven by such views to find out what engineers themselves actually think about corporate branding.

By including engineers' views of the corporate brand in our study of branding in the B2B context, our study has shown how important employees' personal brands can be in these 
contexts. Contrary to popular misconceptions about the lack of regard engineers have about subjects like corporate branding, we discovered that this group of professionals were deeply engaged with, and knowledgeable about, what it was and how it helped them and the company they worked for. Our work, therefore, debunks the myth that corporate branding has little relevance or importance to engineers and with regard to engineering-intensive contexts. Extant literature is heavily characterised by engineering-marketing dichotomy in a way that it suppresses engineers' voices when it comes to the theory and practice of marketing and branding.

We argue that just the opposite approach needs to be adopted. In our opinion, (cynical) engineers are rich sources of insight not only for corporate branding, but more generally for other industrial marketing disciplines, both from a theoretical as well as empirical perspective. In our view, branding of engineering contexts in the literature lags behind the advancements of branding in practice of engineering consulting firms. We would like to suggest that engineering consulting firms, while acknowledging extant corporate branding theories, should continue to innovate upon their own versions of corporate branding in practice. Part of our rationale for making this assertion is because the majority of extant corporate branding theories have developed from business-to-consumer settings, even today. Much more needs to be done to arrive at a point where corporate branding theories meet the specificities of the engineering consulting context. In this regard, we also recommend more critical qualitative research that can grasp the rich intricacies, scepticism, and resistances which emerge to corporate branding activities in $\mathrm{B} 2 \mathrm{~B}$ settings.

Indeed, we contend that any cynicism about the corporate branding process in these organisations can, contrary to expectations, provide valuable insights into how corporate communications can be better managed, particularly in 'macho' settings like the construction, 
shipping or engineering sectors where branding may be regarded as a frivolous, or at best, secondary, priority to service delivery.

Future research could focus on intensive, longitudinal studies of engineering consultancies and thus track how the corporate brand is affected by shifts in the client-employee relationship over time and space. While our research has extended our understanding of B2B branding by showing how external, macro-scale factors can play as significant a role as internal factors in influencing how employees in these contexts perceive corporate branding, more research can still be done on how intra-organizational constructions of corporate branding affect external-facing relationships with stakeholders, including, but not limited, to direct clients.

One case study is clearly insufficient to draw generalizable conclusions about the perceptions of employees about the implications of B2B corporate branding. Furthermore, insights from extant literatures in organization studies, identity theories, and human resource management are particularly useful to be used to understand how professionals in B2B contexts can be motivated to play an increasing role in corporate branding. The implications discussed in this paper equally speak to other disciplines such as engineering management, industrial engineering, organizational behaviour and human resource management. More crossdisciplinary work is, therefore, required to explicate the complexities involved in the corporate branding of engineering-intensive contexts. 


\section{References}

Alvesson, M. (2011) Interpreting Interviews, 1st edn, UK: SAGE Publications.

Alvesson, M. (2004) Knowledge Work and Knowledge-Intensive Firms, 1st edn, USA: Oxford University Press.

Alvesson, M. (2000) 'Social Identity and the Problems of Loyalty in Knowledge-Intensive Companies', Journal of Management Studies, 37 (8): 1101-1123.

Alvesson, M. and Kärreman, D. (2004) 'Interfaces of Control. Technocratic and SocioIdeological Control in a Global Management Consultancy Firm', Accounting, Organizations and Society, 29 (3-4): 423-444.

Antorini, Y.M. and Andersen, K.S. (2005) 'A Communal Approach to Corporate Branding' in Majken Schultz, Yun Mi Antorini and Fabian F. Csaba. (eds) Corporate Branding: Purpose/People/Process, 1st edn, Denmark: CBS Publication. pp. 79-100.

Antorini, Y.M. and Schultz, M. (2005) 'Corporate Branding and the 'Conformity Trap" in Majken Schultz, Yun Mi Antorini and Fabian F. Csaba. (eds) Corporate Branding, 1st edn, Denmark: Copenhagen Business School Press. pp. 57-78.

Backhaus, K. and Tikoo, S. (2004) 'Conceptualizing and Researching Employer Branding', Career Development International, 9 (5): 501-517.

Balmer, J.M.T. and Greyser, S.A. (2003) Revealing the Corporation : Perspectives on Identity, Image, Reputation and Corporate Branding, London; New York: Routledge.

Balmer, J.M.T. and Greyser, S.A. (2002) 'Managing the Multiple Identities of the Corporation', California Management Review, 44 (3): 72-86.

Balmer, J.M.T. and Soenen, G.B. (1999) 'The Acid Test of Corporate Identity Management ${ }^{\mathrm{TM}}$, Journal of Marketing Management, 15 (1-3): 69-92.

Baumgarth, C. (2010) "'Living the Brand": Brand Orientation in the Business-to-Business Sector', European Journal of Marketing, 44 (5): 653-671.

Baumgarth, C. and Schmidt, M. (2010) 'How Strong is the Business-to-Business Brand in the Workforce? an Empirically-Tested Model of 'Internal Brand Equity' in a Business-toBusiness Setting', Industrial Marketing Management, 39 (8): 1250-1260.

Beverland, M., Napoli, J. and Lindgreen, A. (2007) 'Industrial Global Brand Leadership: A Capabilities View', Industrial Marketing Management, 36 (8): 1082-1093.

Blombäck, A. and Axelsson, B. (2007) 'The Role of Corporate Brand Image in the Selection of New Subcontractors', Journal of Business \& Industrial Marketing, 22 (6): 418-430.

Burmann, C. and Zeplin, S. (2005) 'Building Brand Commitment: A Behavioural Approach to Internal Brand Management', Journal of Brand Management, 12279-300. 
Burmann, C., Jost-Benz, M. and Riley, N. (2009) 'Towards an Identity-Based Brand Equity Model', Journal of Business Research, 62 (3): 390-397.

Burmann, C., Zeplin, S. and Riley, N. (2008) 'Key Determinants of Internal Brand Management Success: An Exploratory Empirical Analysis', 16 (4): 284.

Carmeli, A. and Waldman, D.A. (2009) 'Leadership, Behavioral Context, and the Performance of Work Groups in a Knowledge-Intensive Setting', Journal of Technology Transfer, 35 (4): 384-400.

Charters, S. (2009) 'Does a Brand have to be Consistent?', Journal of Product \& Brand Management, 18 (4): 284-291.

Davis, D.F., Golicic, S.L. and Marquardt, A.J. (2008) 'Branding a B2B Service: Does a Brand Differentiate a Logistics Service Provider?', Industrial Marketing Management, 37 (2): 218-227.

de Chernatony, L. and Dall'Olmo Riley, F. (1998) 'Modelling of the Components of the Brand', European Journal of Marketing, 32 (11-12): 1074(1).

de Chernatony, L. (1999) 'Brand Management through Narrowing the Gap between Brand Identity and Brand Reputation', Journal of Marketing Management, 15 (1-3): 157-179.

de Chernatony, L. and Segal-Horn, S. (2003) 'The Criteria for Successful Services Brands', European Journal of Marketing, 37 (7-8): 1095(24).

Downey, G.L. and Lucena, J.C. (2004) 'Knowledge and Professional Identity in Engineering: Code-Switching and the Metrics of Progress', History and Technology, 20 (4): 393-420.

Edwards, M.R. (2010) 'An Integrative Review of Employer Branding and OB Theory', Personnel Review, 39 (1): 5-23.

Filiatrault, P. and Lapierre, J. (1997) 'Managing Business-to-Business Marketing Relationships in Consulting Engineering Firms', Industrial Marketing Management, 26 (2): 213-222.

Glynn, M.S., Motion, J. and Brodie, R.J. (2007) 'Sources of Brand Benefits in ManufacturerReseller B2B Relationships', Journal of Business \& Industrial Marketing, 22 (6): 400409.

Gray, E.R. and Balmer, J.M.T. (1998) 'Managing Corporate Image and Corporate Reputation', Long Range Planning, 31 (5): 695-702.

Greenwood, R. and Empson, L. (2003) 'The Professional Partnership: Relic Or Exemplary Form of Governance?', Organization Studies, 24 (6): 909-933.

Greenwood, R., Suddaby, R. and McDougald, M. (2006) Professional Service Firms, Amsterdam ; Oxford: Elsevier JAI. 
Gummesson, E. (2005) 'Qualitative Research in Marketing: Road-Map for a Wilderness of Complexity and Unpredictability', European Journal of Marketing, 39 (3/4): 309-327.

Gummesson, E. (2000) Qualitative Methods in Management Research, 2nd edn, Thousand Oaks, Calif.: Sage Publications.

Hatch, M.J. and Schultz, M. (2008) Taking Brand Initiative: How Companies can Align Strategy, Culture, and Identity through Corporate Branding, USA: John Wiley and Sons.

Hatch, M.J. and Schultz, M. (2003) 'Bringing the Corporation into Corporate Branding', European Journal of Marketing, 37 (7-8): 1041(24).

Hatch, M.J. and Schultz, M. (2001) 'Are the Strategic Stars Aligned for Your Corporate Brand?', Harvard Business Review, 79 (2): 128-134.

Hearn, A. (2008) "Meat, Mask, Burden': Probing the Contours of the Branded 'Self", Journal of Consumer Culture, 8 (2): 197-217.

Holt, D.B. (2002) 'Why do Brands Cause Trouble? A Dialectical Theory of Consumer Culture and Branding', The Journal of Consumer Research, 29 (1): pp. 70-90.

Ind, N. (2004) Living the Brand: How to Transform Every Member of Your Organization into a Brand Champion, 2nd edn, London: Kogan Page.

Järventie-Thesleff, R., Moisander, J. and Laine, P.-. (2011) 'Organizational Dynamics and Complexities of Corporate Brand Building-A Practice Perspective', Scandinavian Journal of Management, 27 (2): 196-204.

Jennings, J.E., Jennings, P.D. and Greenwood, R. (2009) 'Novelty and New Firm Performance: The Case of Employment Systems in Knowledge-Intensive Service Organizations', Journal of Business Venturing, 24 (4): 338-359.

Jurg, W., Bloemer, J., Doorewaard, H., Peelen, E. and Simons, R. (2008) 'Systems Constellations: A Better Way to Identify Branding Opportunities?', Journal of Brand Management, 15 (4): 239-257.

Kärreman, D. and Rylander, A. (2008) 'Managing Meaning through Branding — the Case of a Consulting Firm', Organization Studies, 29 (1): 103-125.

King, C. and Grace, D. (2008) 'Internal Branding: Exploring the Employee's Perspective', Journal of Brand Management, 15 (5): 358-372.

Knox, S. and Bickerton, D. (2003) 'The Six Conventions of Corporate Branding', European Journal of Marketing, 37 (7/8): 998-1016.

Knox, S., Maklan, S. and Thompson, K.E. (2000) 'Building the Unique Organization Value Proposition' in Mary Jo Hatch, Majken Schultz and M. H. Larsen. (eds) The Expressive Organization: Linking Identity, Reputation and the Corporate Brand, Oxford: Oxford University Press. pp. 138-153. 
Kotler, P. and Pfoertsch, W. (2007) 'Being Known Or being One of Many: The Need for Brand Management for Business-to-Business (B2B) Companies', Journal of Business \& Industrial Marketing, 22 (6): 357-362.

Kotler, P., Pfoertsch, W. and Michi, I. (2006) B2B Brand Management, Berlin: Springer.

Kunda, G. (2006) Engineering Culture: Control and Commitment in a High-Tech Corporation, 2 nd edn, Philadelphia: Temple University Press.

Lynch, J. (2004) 'The Power of Emotion: Brand Communication in Business-to-Business Markets', Journal of Brand Management, 11 (5): 403-419.

Lynch, J. and Chernatony, L.d. (2007) 'Winning Hearts and Minds: Business-to-Business Branding and the Role of the Salesperson', Journal of Marketing Management, 23 (1): 123-135.

McQuiston, D.H. (2004) 'Successful Branding of a Commodity Product: The Case of RAEX LASER Steel', Industrial Marketing Management, 33 (4): 345-354.

Moroko, L. and Uncles, M.D. (2008) 'Characteristics of Successful Employer Brands', Journal of Brand Management, 16 (3): 160-175.

Mudambi, S. (2002) 'Branding Importance in Business-to-Business Markets: Three Buyer Clusters', Industrial Marketing Management, 31 (6): 525-533.

Mudambi, S., Doyle, P. and Wong, V. (1997) 'An Exploration of Branding in Industrial Markets', Industrial Marketing Management, 26 (5): 433-446.

Ohnemus, L. (2009) 'B2B Branding: A Financial Burden for Shareholders?', Business Horizons, 52 (2): 159-166.

Olins, W. (2003) On Brand, London: Thames \& Hudson.

Persson, N. (2010) 'An Exploratory Investigation of the Elements of B2B Brand Image and its Relationship to Price Premium', Industrial Marketing Management, 39 (8): 12691277.

Powell, S. and Dodd, C. (2007) 'Managing Vision and the Brand within the Creative Industries', Corporate Communications: An International Journal, 12 (4): 394-413.

Punjaisri, K. and Wilson, A. (2007) 'The Role of Internal Branding in the Delivery of Employee Brand Promise', Journal of Brand Management, 15 (1): 57-70.

Roberts, J. and Merrilees, B. (2007) 'Multiple Roles of Brands in Business-to-Business Services', Journal of Business \& Industrial Marketing, 22 (6): 410-417.

Schultz, M., Antorini, Y.M. and Csaba, F.F. (2005) 'Corporate Branding - an Evolving Concept' in Majken Schultz, Yun Mi Antorini and Fabian F. Csaba. (eds) Corporate Branding, 1st edn, Denmark: CBS Press. pp. 9-22. 
Schultz, M. and Hatch, M.J. (2003) 'The Cycles of Corporate Branding: THE CASE OF THE LEGO COMPANY', California Management Review, 46 (1): 6-26.

Shaw, J., Giglierano, J. and Kallis, J. (1989) 'Marketing Complex Technical Products: The Importance of Intangible Attributes', Industrial Marketing Management, 18 (1): 45-53.

Shepherd, I.D.H. (2005) 'From Cattle and Coke to Charlie: Meeting the Challenge of Self Marketing and Personal Branding', Journal of Marketing Management, 21 (5): 589-606.

Sheth, J. and Sharma, A. (2006) 'The Surpluses and Shortages in Business-to-Business Marketing Theory and Research', Journal of Business \& Industrial Marketing, 21 (7): 422-427.

Shipley, D. and Howard, P. (1993) 'Brand-Naming Industrial Products', Industrial Marketing Management, 22 (1): 59-66.

Stake, R.E. (2005) 'Qualitative Case Studies' in N. K. Denzin and Y. S. Lincoln. (eds) The Sage Handbook of Qualitative Research, 3rd edn, UK: Sage. pp. 443-467.

Starbuck, W.H. (1992) 'Learning by Knoeledge-Intensive Firms', Journal of Management Studies, 29 (6): 713-740.

Tesch, R. (1990) Qualitative Research : Analysis Types and Software Tools, London: Falmer.

Tonso, K.L. (2006) 'Student Engineers and Engineer Identity: Campus Engineer Identities as Figured World', Cultural Studies of Science Education, 1 (2): 273-307.

Urde, M. (2003) 'Core Value-Based Corporate Brand Building', European Journal of Marketing, 37 (7-8): 1017(24).

van Riel, A.C.R., Pahud de Mortanges, C. and Streukens, S. (2005) 'Marketing Antecedents of Industrial Brand Equity: An Empirical Investigation in Specialty Chemicals', Industrial Marketing Management, 34 (8): 841-847.

Wallace, E. and Chernatony, L.d. (2007) 'Exploring Managers' Views about Brand Saboteurs', Journal of Marketing Management, 23 (1): 91-106.

Whittington, K.B., Owen-Smith, J. and Powell, W.W. (2009) 'Networks, Propinquity, and Innovation in Knowledge-Intensive Industries', Administrative Science Quarterly, 54 (1): 90-122.

Yin, R.K. (2003) Applications of Case Study Research, 2nd edn, Thousand Oaks ; London: Sage. 